\title{
Electron Microscopic Observations of Flavobacterium aquatile NCIB 8694 (= ATCC 11947) and Flavobacterium meningosepticum NCTC 10016 (= ATCC 13253)
}

\author{
K. S. THOMSON, ${ }^{1}$ T. A. McMEEKIN, ${ }^{2}$ aND C. J. THOMAS ${ }^{2}$ \\ Repatriation General Hospital, Hobart, Tasmania, 7000, ${ }^{1}$ and Department of Agricultural Science, \\ University of Tasmania, Hobart, Tasmania, 7001, ${ }^{2}$ Australia
}

Electron microscopic observations of Flavobacterium aquatile NCIB 8694 (type strain) revealed the presence of nonflagellar appendages. Similar appendages were not found on Flavobacterium meningosepticum NCTC 10016 (type strain).

As described by Weeks (24) in Bergey's Manual of Determinative Bacteriology, 8th ed., the genus Flavobacterium is heterogeneous and contains 12 species in two sections. Section I species have guanine-plus-cytosine contents in the range of 26 to $43 \mathrm{~mol} \%$, and section II strains have guanine-plus-cytosine contents in the range of 63 to $70 \mathrm{~mol} \%$.

There are conflicting reports about the presence and arrangement of flagella on strains of Flavobacterium. Weeks (24) described section II organisms as nonmotile or motile and peritrichous, but Yabuuchi et al. (25) showed that one of these organisms, Flavobacterium devorans ATCC 10829 (type strain), has a single polar flagellum and is a strain of Pseudomonas paucimobilis (9). Deoxyribonucleic acid-ribonucleic acid hybridization studies by Bauwens (3) indicated that Flavobacterium capsulatum ATCC 14666 (type strain) is closely related to $F$. devorans ATCC 10829, and consequently $F$. capsulatum may also be synonymous with $P$. paucimobilis. Therefore, it is necessary to examine all strains with high guanine-plus-cytosine contents for flagella regardless of the results of motility tests.

In addition, the section II strains Flavobacterium indoltheticum ATCC 27950 (type strain) and "Flavobacterium tirrenicum" ATCC 15997 have low guanine-plus-cytosine contents (B. Holmes and R. J. Owen, personal communication). (Names in quotation marks are not on the Approved Lists of Bacterial Names [21] and have not been validly published since 1 January 1980; therefore, they do not have nomenclatural standing.) Weeks (24) described the former as motile and peritrichous and the latter as motile, although the type of flagellation was not reported. Obviously, the motility status and flagellum arrangements of these strains require reevaluation.

Weeks (24) also stated that all section I strains were nonmotile, and flagella were assumed to be absent until the report (22) of single polar or lateral flagella on Flavobacterium aquatile ATCC 11947 (type strain) and Flavobacterium meningosepticum ATCC 13253 (type strain) (22). If substantiated, this finding undoubtedly will lead to further confusion and controversy concerning the taxonomy of Flavobacterium. In this paper we report the results of an electron microscopic examination of $F$. aquatile NCIB 8694 and $F$. meningosepticum NCTC 10016.

\section{MATERIALS AND METHODS}

Bacterial strains. The strains of $F$. aquatile and $F$. meningosepticum studied were the same strains used by Webster and Hugh (22) and were obtained from the National Collection of Type Cultures, Central Public Health Laboratory, London, England, and the National Collection of Industrial Bacteria, Torry Research Station, Aberdeen, Scotland. These strains were as follows: $F$. aquatile NCIB 8694 (= ATCC $11947)$ and $F$. meningosepticum NCTC 10016 (= ATCC 13253). We also examined strains of Pseudomonas that were isolated from the water supply at the Repatriation General Hospital, Hobart, Australia.

Characterization of strains. The tests used to characterize the strains are shown in Tables 1 and 2 for $F$. aquatile and $F$. meningosepticum, respectively.

Light microscopy. Bacteria were grown on Oxoid nutrient agar at $30^{\circ} \mathrm{C}$ for 2 or 4 days. Cells were harvested, and suspensions in deionized water were prepared and stained for flagella by the methods of Leifson (14) and Mayfield and Inniss (15).

Electron microscopy. The suspensions prepared for light microscopy were transferred to Formvarcoated grids and were negatively stained with $1 \%$ (wt/ vol) uranyl acetate. Stained specimens were observed with a Hitachi model $\mathrm{H} 300$ transmission electron microscope. Electron microscopic observations were also made on suspensions of F. aquatile NCIB 8694 and $F$. meningosepticum NCTC 10016 that were prepared after culture from freeze-dried National Collection of Industrial Bacteria and National Collection of Type Cultures preparations. 


\section{RESULTS AND DISCUSSION}

Tables 1 and 2 show the results of the tests used to characterize $F$. aquatile NCIB 8694 and $F$. meningosepticum NCTC 10016, along with data from the literature. The results which we obtained were substantially the same as those previously reported. The only discrepancy encountered for $F$. aquatile NCIB 8694 was in gelatin liquefaction, and this discrepancy was attributed to the use of different methods. In this study, charcoal gelatin disks (Oxoid) were incubated with $F$. aquatile NCIB 8694 in nutrient broth for 7 days at $30^{\circ} \mathrm{C}$. The short incuba- tion period and poor growth of this strain in high-peptone liquid medium (24) explained the negative results obtained. Cultures of $F$. meningosepticum NCTC 10016 produced weakly positive results in the test for acid from xylose, whereas Weeks (24) reported a negative reaction and Owen and Lapage (20) recorded a positive result in an $\mathrm{O}-\mathrm{F}$ test aerobic tube. The characteristics of the strains examined by microscopy directly after culture from freeze-dried preparations were also consistent with published data.

Flagella were not observed in 2- or 4-day-old cultures of $F$. meningosepticum NCTC 10016 by either of the staining methods used $(14,15)$,

TABLE 1. Characteristics of F. aquatile NCIB 8694

\begin{tabular}{|c|c|c|c|c|c|}
\hline \multirow[b]{2}{*}{ Test } & \multicolumn{2}{|c|}{ Results of: } & \multirow[b]{2}{*}{ Test } & \multicolumn{2}{|c|}{ Results of: } \\
\hline & Weeks $^{a}$ & $\begin{array}{l}\text { This } \\
\text { study }\end{array}$ & & Weeks $^{a}$ & $\begin{array}{l}\text { This } \\
\text { study }\end{array}$ \\
\hline Motility & - & $-{ }^{b}$ & Phenylalanine deaminase & & $-l$ \\
\hline Gliding motility & - & $-^{c}$ & Voges-Proskauer & & $-l$ \\
\hline Spreading growth & - & $--^{c}$ & Citrate utilization & - & $-{ }^{\prime}$ \\
\hline Filament formation & + & $+^{d}$ & Phosphatase & & $-{ }^{0}$ \\
\hline $\begin{array}{l}\text { Colonies } 1-3 \mathrm{~mm} \text { in diam- } \\
\text { eter, smooth, entire, } \\
\text { glistening }\end{array}$ & + & $+^{e}$ & $\begin{array}{l}\text { Acid from: } \\
\text { Arabinose } \\
\text { Dulcitol }\end{array}$ & & $-l$ \\
\hline Pigmentation & Yellow-orange & Yellow $^{e}$ & Glucose & + & $t^{l}$ \\
\hline Growth in nutrient broth & Poor & Poor $_{d}^{d}$ & Galactose & & $-{ }^{\prime}$ \\
\hline $\begin{array}{l}\text { Even turbidity } \\
\text { Growth at } 37^{\circ} \mathrm{C}\end{array}$ & - & $+_{d}^{d}$ & Glycerol & & $-{ }^{l}$ \\
\hline $\begin{array}{l}\text { Growth at } 37^{\circ} \mathrm{C} \\
\text { Growth on blood agar }\end{array}$ & & $-{ }_{f}^{d}$ & Lactose & - & $-{ }^{l}$ \\
\hline $\begin{array}{l}\text { Growth on blood agar } \\
\text { Growth on MacConkey }\end{array}$ & & $-f$ & Maltose & + & $+{ }^{l}$ \\
\hline $\begin{array}{l}\text { Growth on MacConkey } \\
\text { no. } 3 \text { agar }\end{array}$ & & - & $\begin{array}{l}\text { Raffinose } \\
\text { Salicin }\end{array}$ & & $-_{-l}^{l}$ \\
\hline Growth in inorganic salts & & $-g$ & Sorbitol & & $-l$ \\
\hline plus glucose & & & Sucrose & + & $+{ }^{l}$ \\
\hline Oxidase & & $+_{i}^{n}$ & Xylose & & $-l$ \\
\hline Deoxyribonuclease & & $-{ }^{i}$ & Agar hydrolysis & - & $-^{e}$ \\
\hline O-F test (glucose) ${ }^{j}$ & & $-{ }^{k}$ & Esculin hydrolysis & & $-l$ \\
\hline Urease & - & - & Gelatin hydrolysis & + & $-p$ \\
\hline $\mathrm{H}_{2} \mathrm{~S}$ production & - & $-l$ & $\beta$-Lactamase production & & $-q$ \\
\hline $\mathrm{ONPG}^{m}$ & & $-l$ & Ultraviolet sensitivity & & $+^{r}$ \\
\hline $\begin{array}{l}\text { Indole production } \\
\text { Malonate utilization }\end{array}$ & - & $-^{n}$ & & & \\
\hline Malonate utılization & & & & & \\
\hline
\end{tabular}

\footnotetext{
${ }^{a}$ See reference 24.

${ }^{b}$ Wet mount and motility test medium (BBL Microbiology Systems).

${ }^{c}$ See reference 1.

${ }^{d}$ Nutrient broth (Oxoid).

e Nutrient agar (Oxoid).

${ }^{\prime}$ Columbia agar base (Oxoid) plus defibrinated horse blood (5\%, wt/vol).

${ }^{b}$ See reference 7 .

${ }^{h}$ See reference 13.

${ }^{i}$ Deoxyribonuclease agar (Oxoid).

${ }^{j} \mathrm{O}$-F aerobic tubes.

${ }^{k}$ See reference 10 .

' Minitek system (BBL).

${ }^{m}$ ONPG, $o$-Nitrophenyl- $\beta$-D-glactopyranoside.

${ }^{n}$ Tryptone water (Oxoid) $(1 \%$, wt/vol).

${ }^{o}$ See reference 2.

${ }^{p}$ Charcoal gelatin disks (Oxoid).

${ }^{q}$ See reference 19.

${ }^{r}$ See reference 16.
} 


\begin{tabular}{|c|c|c|c|c|c|}
\hline \multirow[b]{2}{*}{ Test } & \multicolumn{5}{|c|}{ Results of: } \\
\hline & Weeks $^{a}$ & $\begin{array}{l}\text { McMeekin } \\
\text { et al. }^{b}\end{array}$ & $\begin{array}{l}\text { Owen and } \\
\text { Lapage }^{c}\end{array}$ & King $^{d}$ & This study \\
\hline Motility & - & & - & - & $-e$ \\
\hline Gliding motility & - & & & & $-f$ \\
\hline Spreading growth & - & & - & & $-f$ \\
\hline Filament formation & + & & & & $+^{g}$ \\
\hline $\begin{array}{l}\text { Colonies } 1-3 \mathrm{~mm} \text { in diameter, smooth, entire, } \\
\text { glistening, butyrous, translucent }\end{array}$ & + & & & & $t^{h}$ \\
\hline Pigmentation & Yellow & & & & Yellow ${ }^{h}$ \\
\hline Even turbidity & & & & & $+g$ \\
\hline Growth at $37^{\circ} \mathrm{C}$ & + & + & + & + & $t^{g}$ \\
\hline Growth on MacConkey agar & Poor & & $5 / 6^{i}$ & Poor & + \\
\hline Growth in inorganic salts plus glucose & & & & & $-j$ \\
\hline Hemolysis & - & & - & & $--^{k}$ \\
\hline Oxidase & & + & + & + & $+^{l}$ \\
\hline Deoxyribonuclease & & & & & $t^{m}$ \\
\hline O-F test (glucose) ${ }^{n}$ & & & & & $t^{\circ}$ \\
\hline Urease & - & & - & - & $\perp^{p}$ \\
\hline $\mathrm{H}_{2} \mathrm{~S}$ (lead acetate) & + & & + & + & \\
\hline $\mathrm{H}_{2} \mathrm{~S}$ (triple sugar iron) & - & & & - & $-^{p}$ \\
\hline $\mathrm{ONPG}^{q}$ & & & & & $t^{p}$ \\
\hline Indole production & + & & + & + & $t^{r}$ \\
\hline Malonate utilization & & & - & & $p$ \\
\hline Citrate utilization & Variable & & - & & $\perp^{p}$ \\
\hline Phenylalanine deaminase & & & - & & $-p$ \\
\hline Voges-Proskauer & & & - & - & $\perp^{p}$ \\
\hline \multicolumn{6}{|l|}{ Acid from: } \\
\hline Arabinose & - & & & & $-^{p}$ \\
\hline Dulcitol & & & & & $-p$ \\
\hline Galactose & - & & & & $-p$ \\
\hline Glucose & + & + & - & & $t^{p}$ \\
\hline Glycerol & & & & & $+^{p}$ \\
\hline Lactose & + & & + & & $+^{p}$ \\
\hline Maltose & + & & & & $+^{p}$ \\
\hline Raffinose & - & & & & $p$ \\
\hline Salicin & - & & & & $-p$ \\
\hline Sorbitol & & & & & $-p$ \\
\hline Sucrose & - & & - & & \lrcorner$^{p}$ \\
\hline Xylose & - & & $t^{n}$ & & $\mathrm{Weak}^{p}$ \\
\hline Esculin hydrolysis & & & & & $t^{p}$ \\
\hline Gelatin hydrolysis & + & & + & & $+^{8}$ \\
\hline Phosphatase & & & + & & $t^{t}$ \\
\hline$\beta$-Lactamase production & & & & & $t^{n}$ \\
\hline Ultraviolet sensitivity & & & & & $t^{v}$ \\
\hline
\end{tabular}

${ }^{a}$ See reference 24 .

${ }^{b}$ See reference 17 .

${ }^{c}$ See reference 20.

${ }^{d}$ See reference 12 .

' Wet mount and motility test medium (BBL).

${ }^{f}$ See reference 1.

${ }^{g}$ Nutrient broth (Oxoid).

${ }^{h}$ Nutrient agar (Oxoid).

${ }^{i} 5 / 6$, Five of six strains tested grew on MacConkey agar.

${ }^{j}$ See reference 7 .

${ }^{k}$ Columbia agar base (Oxoid) plus defibrinated horse blood $(5 \%$, wt/vol).

${ }^{l}$ See reference 13.

${ }^{m}$ Deoxyribonuclease agar (Oxoid).

${ }^{n}$ O-F aerobic tubes.

${ }^{\circ}$ See reference 10.

${ }^{p}$ Minitek system (BBL).

${ }^{q}$ ONPG, $o$-Nitrophenyl- $\beta$-D-galactopyranoside.

$r$ Tryptone water (Oxoid) (1\%, wt/vol).

${ }^{s}$ Charcoal gelatin disks (Oxoid).

'See reference 12.

"See reference 19.

${ }^{v}$ See reference 16. 
although some cells of $F$. aquatile NCIB 8694 exhibited faintly stained strands when they were examined by the method of Mayfield and Inniss (15). Flagella were observed in stained preparations of Pseudomonas isolates examined by light microscopy. However, these results cannot be compared directly with the observations of Webster and Hugh (22) because the incubation temperatures were different and the cells examined in our study were not formalinized.

Electron microscopic examinations of $F$. meningosepticum NCTC 10016 and F. aquatile NCIB 8694 were performed in an attempt to provide more definitive evidence of appendages associated with these strains. Again, the results for $F$. meningosepticum NCTC 10016 were negative (Fig. 1a), and structures equivalent to the appendages described by Webster and Hugh (22) could not be located. To confirm the authenticity of the strain being examined and to overcome the possibility of the loss of this feature during repeated subculturing, an additional culture of $F$. meningosepticum NCTC 10016 was prepared from the freeze-dried state, checked for purity, and examined without further subculturing. Again, a negative result was obtained. One to three polar flagella were observed on the cells of the Pseudomonas strains used as controls, indicating the efficacy of the technique.

All electron microscopic observations of $F$. aquatile NCIB 8694 revealed the presence of extracellular appendages protruding from the cell surface (Fig. 1b and d). Some appendages had terminal swellings (Fig. 1e), and the cell
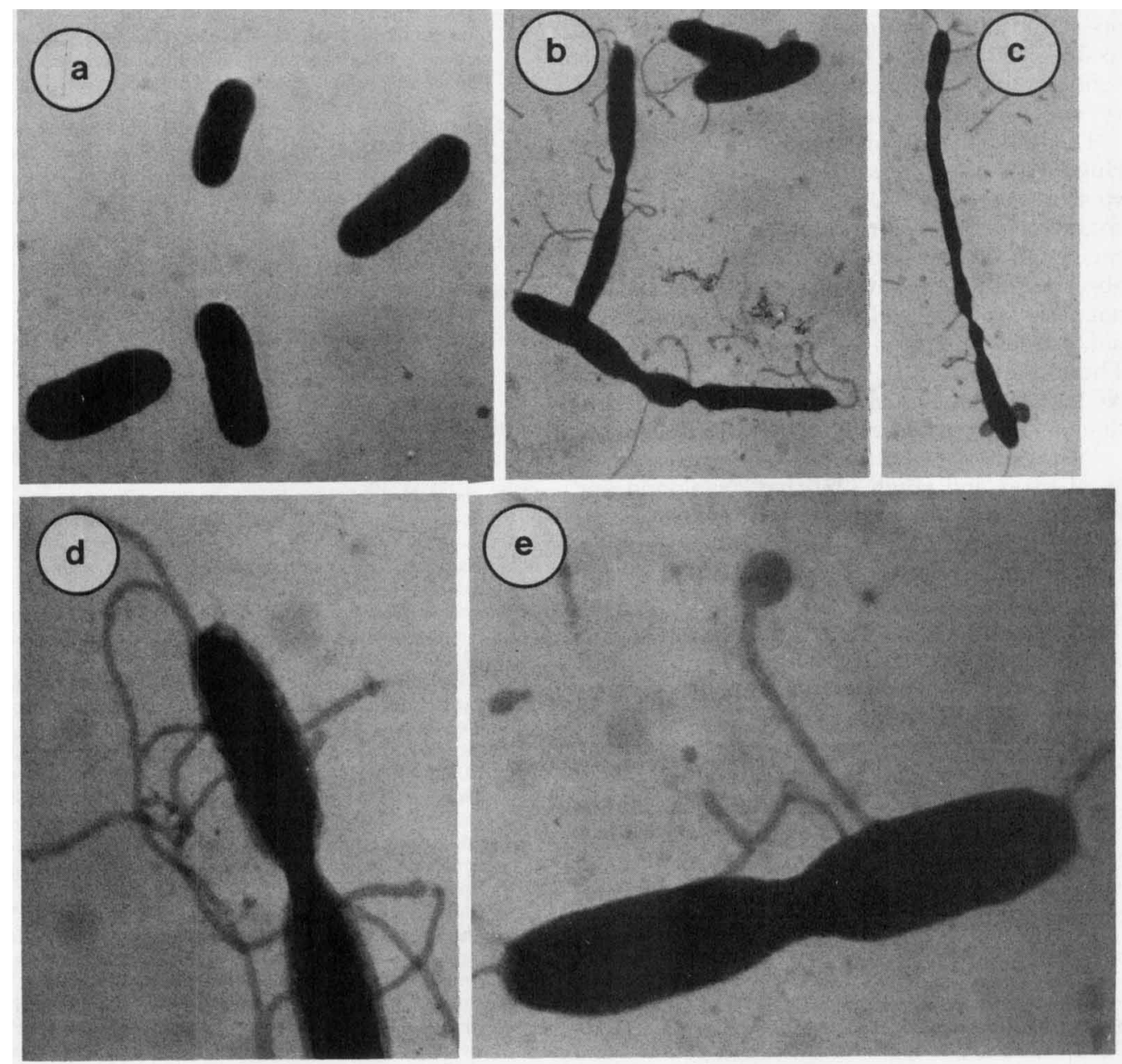

Fig. 1. Negatively stained preparations. (a) F. meningosepticum NCTC 10016. $\times 15,000$. (b) F. aquatile NCIB 8694 cells showing appendages. $\times 10,000$. (c) Chain of $F$, aquatile NCIB 8694 cells. $\times 7,000$. (d) Same as (b), except $\times 30,000$. (e) Appendage with terminal swelling. $\times 30,000$. 
morphology of $F$. aquatile NCIB 8694 varied from individual rods $(\simeq 0.5$ by $1.5 \mu \mathrm{m})$ to elongated chains $\simeq 8 \mu \mathrm{m}$ or more long (Fig. 1c). The appendages were morphologically similar to those described by Follett and Webley (4) for Myxococcus xanthus and Cytophaga johnsonae and by Humphrey et al. (11) for Flexibacter BH3. Humphrey et al. provided substantial evidence to show that the appendages were part of the outer membrane of the cell. Follett and Webley (4) also studied $F$. aquatile and noted "a remarkable and unexpected morphological similarity between this organism and C. johnsonae," and Weeks (23) noted the presence of pseudoflagellae on $F$. aquatile. Further detailed observations will be required to confirm that the appendages observed on strain NCIB 8694 are the same as the appendages reported on gliding bacteria. However, the morphological evidence presented and the many characteristics common to flavobacteria with low guanine-plus-cytosine contents and to Cytophaga and Flexibacter (8, 18 ) suggest that this is probable.

The appendages observed by Webster and Hugh (22) on $F$. aquatile NCIB 8694 and $F$. meningosepticum NCTC 10016 require further characterization before their taxonomic significance can be assessed. These appendages were observed only on a few cells of both strains, did not show typical flagellar morphology, and could not be demonstrated by electron microscopy. Therefore, it is our opinion that $F$. aquatile NCIB 8694 and F. meningosepticum should continue to be regarded as nonflagellate organisms.

Furthermore, we cannot support the assertion of Webster and Hugh (22) that Frankland and Frankland $(5,6)$ originally described $F$. aquatile as a motile organism. An alternative interpretation of the description of Frankland and Frankland $(5,6)$ of vibratory movements only and filaments up to $17 \mu \mathrm{m}$ long is that these authors observed a Cytophaga-like organism $(8,18)$. It is interesting to note the following descriptions of other motile bacteria by Frankland and Frankland (6): "Bacillus fluorescens aureus," "it is very motile and has cilia attached," "Bacillus aurantiacus," "the individual bacilli are motile," and "Bacillus phosphorescens indicus," "it is very motile." Clearly, Frankland and Frankland (6) distinguished between typical motility and vibratory movement only.

\section{REPRINT REQUESTS}

Address reprint requests to: Dr. T. A. McMeekin, Department of Agricultural Science, University of Tasmania, G.P.O. Box 252C, Hobart, Tasmania, 7001, Australia.

\section{LITERATURE CITED}

1. Anacker, R. L., and E. J. Ordal. 1959. Studies on the myxobacterium Chondrococcus columnaris. I. Serological typing. J. Bacteriol. 78:25-32.

2. Barber, M., and S. W. A. Kuper. 1951. Identification of Staphylococcus pyogenes by the phosphatase reaction. J. Pathol. Bacteriol. 63:65-68.

3. Bauwens, M. 1980. Intrageneric and intergeneric similarities of ribosomal ribonucleic acid cistrons of Flavobacterium. Antonie van Leeuwenhoek J. Microbiol. Serol. 46:95.

4. Follett, E. A. C., and D. M. Webley. 1965. An electron microscope study of the cell surface of Cytophaga johnsonae and some observations on related organisms. Antonie van Leeuwenhoek J. Microbiol. Serol. 31:361382.

5. Frankland, G. C., and P. F. Frankland. 1889. Ueber einige typische Mikroorganismen im Wasser und im Boden. Z. Hyg. Infektionskr. 6:373-400.

6. Frankland, G. C., and P. F. Frankland. 1894. Microorganisms in water. Longmans, Green, and Co., London.

7. Hayes, P. R. 1977. A taxonomic study of flavobacteria and related gram negative yellow pigmented rods. J. Appl. Bacteriol. 43:345-367.

8. Holmes, B., and R. J. Owen. 1979. Proposal that Flavobacterium breve be substituted as the type species of the genus in place of Flavobacterium aquatile and emended description of the genus Flavobacterium: status of the named species of Flavobacterium. Int. J. Syst. Bacteriol. 29:416-426.

9. Holmes, B., R. J. Owen, A. Evans, H. Malnick, and W. R. Willcox. 1977. Pseudomonas paucimobilis, a new species isolated from human clinical specimens, the hospital environment, and other sources. Int. J. Syst. Bacterol. 27: 133-146.

10. Hugh, R., and E. Leifson. 1953. The taxonomic significance of fermentative versus oxidative metabolism of carbohydrates by various gram-negative bacteria. $\mathrm{J}$. Bacteriol. 66:24-26.

11. Humphrey, B. A., M. R. Dickson, and K. C. Marshall. 1979. Physicochemical and in situ observations on the adhesion of gliding bacteria to surfaces. Arch. Microbiol. 120:231-238.

12. King, E. O. 1959. Studies on a group of previously unclassified bacteria associated with meningitis in infants. Am. J. Clin. Pathol. 31:241-247.

13. Kovacs, N. 1956. Identification of Pseudomonas pyocyanea by the oxidase reaction. Nature (London) 178: 703.

14. Leifson, E. 1951. Staining, shape, and arrangement of bacterial flagella. J. Bacteriol. 62:377-389.

15. Mayfield, C. I., and W. E. Inniss. 1977. A rapid, simple method for staining bacterial flagella. Can. J. Microbiol. 23: 1311-1313.

16. McMeekin, T. A. 1977. Ultraviolet light sensitivity as an aid for the identification of gram negative yellow pigmented rods. J. Gen. Microbiol. 103:149-151.

17. McMeekin, T. A., J. T. Patterson, and J. G. Murray. 1971. An initial approach to the taxonomy of some gram negative, yellow pigmented rods. J. Appl. Bacteriol. 34: 699-716.

18. McMeekin, T. A., and J. M. Shewan. 1978. Taxonomic strategies for Flavobacterium and related genera. J. Appl. Bacteriol. 45:321-332.

19. O'Callaghan, C. H., A. Morris, S. Kirby, and A. H. Shingler. 1972. Novel method for detection of $\beta$-lactamases by using a chromogenic cephalosporin substrate. Antimicrob. Agents Chemother. 1:283-288.

20. Owen, R. J., and S. P. Lapage. 1974. A comparison of strains of King's group IIb of Flavobacterium with $F$. meningosepticum. Antonie van Leeuwenhoek J. Microbiol. Serol. 40:255 264.

21. Skerman, V. B. D., V. McGowan, and P. H. A. Sneath (ed.). 1980. Approved lists of bacterial names. Int. J. Syst. Bacteriol. 30:225-420. 
22. Webster, J. A., and R. Hugh. 1979. Flavobacterium aquatile and Flavobacterium meningosepticum: glucose nonfermenters with similar flagellar morphologies. Int. J. Syst. Bacteriol. 29:333-338.

23. Weeks, O. B. 1955. Flavobacterium aquatile (Frankland and Frankland) Bergey et al., type species of the genus Flavobacterium. J. Bacteriol. 69:649-658.

24. Weeks, O. B. 1974. Genus Flavobacterium Bergey et al.
1923, 97, p. 357-364. In R. E. Buchanan and N. E. Gibbons (ed.), Bergey's manual of determinative bacteriology, 8th ed. The Williams \& Wilkins Co., Baltimore.

25. Yabuuchi, E., E. Tanimura, A. Ohyama, I. Yano, and A. Yamomoto. 1979. Flavobacterium devorans ATCC 10829: a strain of Pseudomonas paucimobilis. J. Gen. Appl. Microbiol. 25:95-108. 